\title{
Front Matter: Volume 10364
}

, "Front Matter: Volume 10364," Proc. SPIE 10364, Organic Sensors and Bioelectronics X, 1036401 (30 October 2017); doi: 10.1117/12.2297119

Event: SPIE Organic Photonics + Electronics, 2017, San Diego, California, SPIE. United States 


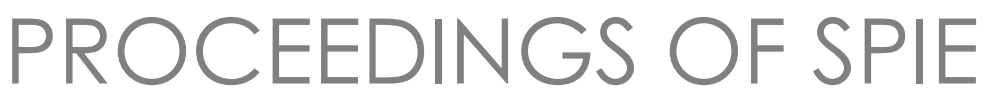

\title{
Organic Sensors and Bioelectronics $X$
}

\author{
loannis Kymissis \\ Ruth Shinar \\ Luisa Torsi \\ Editors
}

\section{6-7 August 2017 \\ San Diego, California, United States}

Sponsored by

SPIE

Cosponsored by

Kolon Industries, Inc. (Korea, Republic of)

Published by

SPIE 
The papers in this volume were part of the technical conference cited on the cover and title page. Papers were selected and subject to review by the editors and conference program committee. Some conference presentations may not be available for publication. Additional papers and presentation recordings may be available online in the SPIE Digital Library at SPIEDigitalLibrary.org.

The papers reflect the work and thoughts of the authors and are published herein as submitted. The publisher is not responsible for the validity of the information or for any outcomes resulting from reliance thereon.

Please use the following format to cite material from these proceedings:

Author(s), "Title of Paper," in Organic Sensors and Bioelectronics $X$, edited by loannis Kymissis, Ruth Shinar, Luisa Torsi, Proceedings of SPIE Vol. 10364 (SPIE, Bellingham, WA, 2017) Seven-digit Article CID Number.

ISSN: 0277-786X

ISSN: 1996-756X (electronic)

ISBN: 9781510611856

ISBN: 9781510611863 (electronic)

Published by

SPIE

P.O. Box 10, Bellingham, Washington 98227-0010 USA

Telephone +1 3606763290 (Pacific Time) · Fax +1 3606471445

SPIE.org

Copyright @ 2017 , Society of Photo-Optical Instrumentation Engineers.

Copying of material in this book for internal or personal use, or for the internal or personal use of specific clients, beyond the fair use provisions granted by the U.S. Copyright Law is authorized by SPIE subject to payment of copying fees. The Transactional Reporting Service base fee for this volume is $\$ 18.00$ per article (or portion thereof), which should be paid directly to the Copyright Clearance Center (CCC), 222 Rosewood Drive, Danvers, MA 01923. Payment may also be made electronically through CCC Online at copyright.com. Other copying for republication, resale, advertising or promotion, or any form of systematic or multiple reproduction of any material in this book is prohibited except with permission in writing from the publisher. The CCC fee code is $0277-$ $786 \times / 17 / \$ 18.00$.

Printed in the United States of America.

Publication of record for individual papers is online in the SPIE Digital Library.

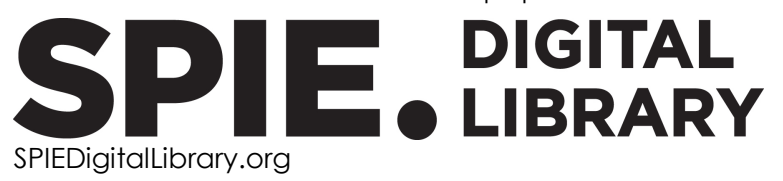

Paper Numbering: Proceedings of SPIE follow an e-First publication model. A unique citation identifier (CID) number is assigned to each article at the time of publication. Utilization of CIDs allows articles to be fully citable as soon as they are published online, and connects the same identifier to all online and print versions of the publication. SPIE uses a seven-digit CID article numbering system structured as follows:

- The first five digits correspond to the SPIE volume number.

- The last two digits indicate publication order within the volume using a Base 36 numbering system employing both numerals and letters. These two-number sets start with $00,01,02,03$, 04, 05, 06, 07, 08, 09, OA, OB ... 0Z, followed by 10-1Z, 20-2Z, etc. The CID Number appears on each page of the manuscript. 


\title{
Contents
}

\author{
$\checkmark$ Authors \\ vii Conference Committee
}

ORGANIC PHOTONICS + ELECTRONICS PLENARY SESSION

1036402 Hybrid electro-optics and chipscale integration of electronics and photonics

(Plenary Paper) [10364-301]

ORGANIC SENSORS AND BIOELECTRONICS V

10364 0J Electrolyte gated TFT biosensors based on the Donnan's capacitance of anchored biomolecules (Keynote Paper) [10364-17]

\section{ORGANIC SENSORS AND BIOELECTRONICS VI}

10364 ON A printed electronic plafform for the specific detection of biomolecules [10364-21]

1036400 Microfluidics and BIO-encapsulation for drug- and cell-therapy (Invited Paper) [10364-22]

POSTER SESSION

$10364 \mathrm{OV}$ Porous silicon photoluminescence biosensor for rapid and sensitive detection of toxins [10364-28] 
Proc. of SPIE Vol. 10364 1036401-4

Downloaded From: https://www.spiedigitallibrary.org/conference-proceedings-of-spie on 25 Apr 2023 Terms of Use: https://www.spiedigitallibrary.org/terms-of-use 


\section{Authors}

Numbers in the index correspond to the last two digits of the seven-digit citation identifier (CID) article numbering system used in Proceedings of SPIE. The first five digits reflect the volume number. Base 36 numbering is employed for the last two digits and indicates the order of articles within the volume. Numbers start with 00, 01, 02, 03, 04, 05, 06, 07, 08, 09, OA, OB...0Z, followed by 10-1Z, 20-2Z, etc.

Aloisi, A., 00

Behrendt, J. M., ON

Dalton, L. R., 02

Di Corato, R., 00

Di Franco, Cinzia, 0J

Doumbia, A., ON

Elder, D. L., 02

Favia, Pietro, 0J

latsunskyi, Igor, OV

Johnson, L. E., 02

Macchia, Eleonora, OJ

Mallardi, Antonia, 0J

Manoli, Kyriaki, OJ

Melnyk, Yulia, OV

Myndrul, Valerii, OV

Palazzo, Gerardo, 0J

Pavlova, Karyna, OV

Rinaldi, R., $0 \mathrm{O}$

Robinson, B. H., 02

Scamarcio, Gaetano, 0J

Smyntyna, Valentyn, OV

Tillack, A. F., 02

Tiwari, Amber, $0 \mathrm{~J}$

Toma, C. C., 00

Torsi, Luisa, OJ

Turner, M. L., ON

Viter, Roman, OV

Webb, M., ON

Wilson, R., ON 
Proc. of SPIE Vol. 10364 1036401-6

Downloaded From: https://www.spiedigitallibrary.org/conference-proceedings-of-spie on 25 Apr 2023 Terms of Use: https://www.spiedigitallibrary.org/terms-of-use 


\title{
Conference Committee
}

\author{
Symposium Chairs
}

Zakya H. Kafafi, Lehigh University (United States)

Ifor D. W. Samuel, University of St. Andrews (United Kingdom)

Conference Chairs

loannis Kymissis, Columbia University (United States)

Ruth Shinar, lowa State University (United States)

Luisa Torsi, Università degli Studi di Bari Aldo Moro (Italy)

Conference Program Committee

Magnus Berggren, Linköping University (Sweden)

Annalisa Bonfiglio, Università degli Studi di Cagliari (Italy)

Fabio Cicoira, Ecole Polytechnique de Montréal (Canada)

Alon Gorodetsky, University of California, Irvine (United States)

Emil J. W. List-Kratochvil, Technische Universität Graz (Austria)

George G. Malliaras, Ecole Nationale Supérieure des Mines de Saint-Étienne (France)

Paul Meredith, The University of Queensland (Australia)

Róisín M. Owens, Ecole Nationale Supérieure des Mines de Saint-

Étienne (France)

Manijeh Razeghi, Northwestern University (United States)

Rosaria Rinaldi, Università del Salento (Italy)

Ifor D. W. Samuel, University of St. Andrews (United Kingdom)

Franky So, North Carolina State University (United States)

\section{Session Chairs}

1 Organic Sensors and Bioelectronics I

loannis Kymissis, Columbia University (United States)

2 Organic Sensors and Bioelectronics II

Paul L. Burn, The University of Queensland (Australia)

3 Organic Sensors and Bioelectronics III

Ruth Shinar, lowa State University of Science and Technology (United States)

4 Organic Sensors and Bioelectronics IV

Paul Meredith, Swansea University (United Kingdom) 
5 Organic Sensors and Bioelectronics $V$

Joseph Shinar, lowa State University of Science and Technology (United States)

6 Organic Sensors and Bioelectronics VI

Luisa Torsi, Università degli Studi di Bari Aldo Moro (Italy)

7 Organic Sensors and Bioelectronics VII

John C. de Mello, Imperial College London (United Kingdom) 